\title{
PENGARUH PEMBERIAN KOMPOS TANDAN KOSONG KELAPA SAWIT DAN PUPUK P TERHADAP PERTUMBUHAN DAN PRODUKSI TANAMAN SERAI (Cymbopogon citratus)
}

\author{
Riyanti \\ Universitas Amir Hamzah Medan \\ riyanti@unhamzah.ac.id
}

\begin{abstract}
Abstrak
Penelitian ini bertujuan untuk mengetahui pengaruh pemberian kompos janjangan sawit dan pupuk $\mathrm{P}$ terhadap pertumbuhan dan produksi tanaman serai (Cymbopogon citratus). Penelitian ini dilaksanakan di Kebun Percobaan Fakultas Pertanian Universitas Amir Hamzah, Medan dengan ketinggian tempat $\pm 25 \mathrm{~m}$ di atas permukaan laut dengan topografi datar. Waktu penelitian dimulai dari bulan Januari sampai Mei 2021. Penelitian ini menggunakan Rancangan Acak Kelompok (RAK) Faktorial yang terdiri dari 2 faktor perlakuan yaitu faktor pertama pemberian kompos tandan kosong kelapa sawit yang terdiri dari 3 taraf, yaitu $\mathrm{K}_{0}=$ kontrol, $\mathrm{K}_{1}=4,5 \mathrm{~kg} / \mathrm{plot}(20$ ton/ha), $\mathrm{K}_{2}=9 \mathrm{~kg} / \mathrm{plot}$ (40 ton/ha) dan faktor kedua adalah pemberian $\mathrm{P}$ dengan 3 taraf, yaitu $\mathrm{P}_{0}=$ kontrol, $\mathrm{P}_{1}=16,875 \mathrm{~g} / \mathrm{plot}(75 \mathrm{~kg} / \mathrm{ha}), \mathrm{P}_{2}=33,75 \mathrm{~g} / \mathrm{plot}(150 \mathrm{~kg} / \mathrm{ha})$. Parameter yang diamati meliputi tinggi tanaman $(\mathrm{cm})$, jumlah anakan tanaman per plot, dan produksi tanaman per plot. Hasil penelitian menunjukkan bahwa pemberian kompos tandan kosong kelapa sawit berpengaruh nyata terhadap semua parameter yang diamati, dimana hasil terbaik diperoleh pada perlakuan $\mathrm{K}_{2}$ $(9 \mathrm{~kg} / \mathrm{plot})$. Pemberian pupuk $\mathrm{P}$ juga berpengaruh nyata terhadap semua parameter yang diamati, dimana hasil terbaik diperoleh pada perlakuan $\mathrm{P}_{2}(33,75 \mathrm{~g} / \mathrm{plot})$. Sementara interaksi antara kompos tandan kosong kelapa sawit dengan pupuk $\mathrm{P}$ tidak berpengaruh nyata terhadap semua parameter yang diamati.
\end{abstract}

Kata kunci: serai, kompos tandan kosong kelapa sawit, pupuk P

\section{PENDAHULUAN}

Di Indonesia terdapat keanekaragaman sumber daya alam hayati, terutama spesies tanaman yang dimanfaatkan sebagai obat. Di kalangan masyarakat tanaman obat dijadikan sebagai obat tradisional karena memiliki kelebihan yaitu mudah diperoleh, harganya yang terjangkau dan dapat diolah sendiri. Salah satu peningkatan pengobatan alternatif adalah dengan meningkatkan penggunaan tumbuhan berkhasiat obat yang bermanfaat sebagai antioksidan bagi tubuh. Antioksidan adalah senyawa kimia yang dapat menghambat reaksi oksidasi dengan menangkal radikal bebas (Winarsi, 2007).

Tanaman serai (Cymbopogon citratus) merupakan salah satu tanaman yang dijadikan bahan dasar obat tradisional, biasanya serai ditanam di pekarangan rumah. Di Indonesia serai (Cymbopogon citratus) merupakan tanaman yang cukup melimpah. Tanaman serai tidak memerlukan perawatan khusus, tanaman ini mudah tumbuh pada berbagai jenis tanah yang memiliki kesuburan yang cukup. Berdasarkan penelitian yang dilakukan oleh Ewansiha $d k k$ (2012), dengan 
menggunakan metode kromatografi lapis tipis diketahui bahwa kandungan fitokimia yang terdapat pada serai adalah tanin flavonoid fenol, karbohidrat dan minyak esensial. Serai dapat berkhasiat sebagai obat sakit kepala, batuk, nyeri lambung, diare, penghangat badan, penurun panas dan pengusir nyamuk (Fauzi, 2009).

Prospek ekonomi tanama serai cukup tinggi, karena tanaman serai memiliki banyak kegunaan seperti bahan masakan, obat, aromaterapi dan pestisida alami. Serai mempunyai nama daerah yaitu serai wangi (Malaysia), citronella grass (Inggris), dan sereh (Indonesia) (Quattrocchi, 2006).

\section{LITERATURE REVIEW}

Pemberian pupuk organik pada budidaya tanaman mampu memperbaiki media tumbuh tanaman dan merupakan sumber hara makro dan mikro. Pemberian dosis dan jenis pupuk organik akan berpengaruh terhadap tanaman. Kompos merupakan hasil dari pelapukan bahan-bahan berupa dedaunan, jerami, alangalang, rumput, kotoran hewan, sampah kota dan sebagainya (Lingga dan Marsono, 2004). Tandan kosong kelapa sawit (TKKS) merupakan limbah padat hasil pabrik kelapa sawit yang jumlahnya cukup banyak, yaitu sekitar 6 juta ton per tahun. Salah satu pemanfaatan TKKS adalah dengan menjadikannya kompos (Purnamayani, 2012).

Pemanfaatan TKKS memiliki potensi yang cukup besar, diantaranya memanfaatkan limbah TKKS sebagai alternatif pembuatan pupuk organik kompos. Puspa (2014) menyatakan, pupuk organik adalah nama kolektif semua jenis bahan organik asal tanaman dan hewan yang dapat dirombak menjadi unsur hara tersedia bagi tanaman. Kompos merupakan hasil dekomposisi sisa tanaman yang dibantu oleh aktivitas mikroorganisme (Jannah $d k k$ 2012). Untuk menjaga kelestarian kandungan bahan organik tanah secara langsung maupun tidak langsung, pengembalian bahan organik berupa TKKS mampu menjaga ketersediaan bahan organik tanah (Surilawati, 2013).

Pemanfaatan kompos TKKS sebagai pupuk organik dapat menyediakan hara secara lengkap dan berimbang walaupun dalam jumlah terbatas dan ketersediaan nutrisinya juga lambat. Simanungkalit (2013) menyatakan, ketersediaan nutrisi pada pupuk organik cukup lambat jika dibandingkan pupuk anorganik, untuk itu sebaiknya dilakukan pengelolaan pupuk terpadu dengan cara mengkombinasikan penggunaan pupuk organik dengan pupuk anorganik diantaranya pupuk NPK. Mubandono (2005) menyatakan bahwa bahan organik yang telah mengalami pengomposan mampu memperbaiki struktur tanah, memperbesar tanah mengikat air, memperbaiki aerase dan draenase tanah sehingga kandungan air mencukupi dan suhu tanah menjadi stabil.

Kekurangan unsur hara akan menyebabkan hambatan dalam pertumbuhan dan gejala-gejala lain yang dapat mengganggu kualitas pertumbuhan tanaman dan pada akhirnya menurunkan penampilan dan kualitas bunga yang dihasilkan (Setiadi $d k k$, 2018). Oleh karena itu penambahan pupuk anorganik dirasa perlu dalam menyuplai hara yang belum tersedia oleh bahan organik, akan tetapi penggunaa pupuk anorganik tidak perlu berlebihan. Pupuk anorganik adalah 
pupuk kimia yang bersifat sintetis. Pemupukan secara anorganik mempunyai kelemahan yaitu harganya yang cukup mahal, merusak sifat fisik, kimia, dan biologi tanah, dan menyebabkan degradasi lahan sehingga efesiensinya menurun akibat sebagian besar pupuk hilang melalui pencucian, fiksasi atau penguapan (Musnamar, 2007).

Berdasarkan uraian diatas penulis tertarik untuk melakukan penelitian tentang pengaruh pemberian kompos janjangan sawit dan pupuk $\mathrm{P}$ terhadap pertumbuhan dan produksi tanaman serai (Cymbopogon citratus).

\section{METODE PENELITIAN}

Penelitian ini dilaksanakan di Kebun Percobaan Fakultas Pertanian Universitas Amir Hamzah, Medan dengan ketinggian tempat $\pm 25 \mathrm{~m}$ di atas permukaan laut dengan topografi datar. Penelitian ini dilaksanakan mulai dari bulan Januari sampai dengan Mei 2021.

Bahan-bahan yang digunakan dalam penelitian ini adalah anakan tanaman serai, kompos janjangan sawit, pupuk $\mathrm{P}$, air, pestisida. Alat-alat yang digunakan dalam penelitian ini adalah cangkul dan garu, gembor dan handsprayer, plat tanaman dan spanduk penelitian, tali plastik dan meteran, alat tulis dan timbangan.

Penelitian dilakukan dengan menggunakan Rancangan Acak Kelompok (RAK) Faktorial yang terdiri dari 2 faktor perlakuan yaitu:

Faktor pertama pemberian kompos janjangan sawit yang terdiri dari 3 taraf, yaitu:

$\mathrm{K}_{0}=$ kontrol

$\mathrm{K}_{1}=4,5 \mathrm{~kg} / \mathrm{plot}(20 \mathrm{ton} / \mathrm{ha})$

$\mathrm{K}_{2}=9 \mathrm{~kg} / \mathrm{plot}$ (40 ton $/ \mathrm{ha}$ ).

Faktor kedua pemberian $\mathrm{P}$ dengan 3 taraf, yaitu:

$\mathrm{P}_{0}=$ kontrol

$\mathrm{P}_{1}=16,875 \mathrm{~g} / \mathrm{plot}(75 \mathrm{~kg} / \mathrm{ha})$

$\mathrm{P}_{2}=33,75 \mathrm{~g} / \mathrm{plot}(150 \mathrm{~kg} / \mathrm{ha})$.

Model linear Rancangan Acak Kelompok (RAK) faktorial yang diasumsikan sebagai berikut:

$$
\text { Yijk }=\mu+\alpha i+\beta j+\rho k+(\alpha \beta) i j+\sum i j k
$$

Dimana:

Yjik = Hasil pengamatan dari faktor pemberian kompos janjangan sawit taraf ke-j dan faktor pemberian pupuk CIRP taraf ke-j dalam ulangan ke-i

$\mu \quad=$ Efek dari nilai tengah.

ai $=$ Efek pemberian pemberian kompos janjangan sawit

$\beta \mathrm{j}=$ Efek pemberian pupuk $\mathrm{P}$

$\rho \mathrm{k}=$ Efek ulangan taraf ke-k.

$(\alpha \beta) \mathrm{ij}=$ Efek kombinasi antara kompos janjangan sawit taraf ke-j dan faktor pemberian pupuk $\mathrm{P}$ taraf ke-k

$\sum \mathrm{ijk}=$ Efek galat dari faktor pemberian kompos janjangan sawit taraf kei dan faktor pemberian pupuk $\mathrm{P}$ taraf ke-j pada ulangan ke-k. 
Jika analisis sidik ragam menunjukkan nyata atau sangat nyata, maka uji dilanjutkan menggunakan uji BNJ jika KK $<10 \%$, uji BNT jika $\mathrm{KK}<10 \%$ $20 \%$, dan uji DMRT jika KK > 20\%.

Parameter yang diamati meliputi tinggi tanaman $(\mathrm{cm})$, jumlah anakan tanaman per plot, produksi tanaman per plot.

\section{HASIL PENELITIAN}

\section{Tinggi Tanaman $(\mathrm{cm})$}

Dari hasil analisa sidik ragam diketahui bahwa pemberian kompos janjangan sawit berpengaruh nyata terhadap seluruh parameter amatan tinggi tanaman serai. Pemberian pupuk $\mathrm{P}$ berpengaruh nyata terhadap seluruh paramter tinggi tanaman serai. Interaksi pemberian kompos janjangan sawit dan pupuk $\mathrm{P}$ menunjukkan tidak berpengruh nyata terhadap seluruh parameter amatan tinggi tanaman serai.

Hasil uji beda rataan pengaruh pemberian kompos janjangan sawit dan pupuk $\mathrm{P}$ terhadap tinggi tanaman serai umur $10 \mathrm{MST}$ dapat dilihat pada tabel 1 berikut ini.

Tabel 1. Hasil Uji Beda Rataan Pengaruh Pemberian Kompos Janjangan Sawit dan Pupuk P Terhadap Tinggi Tanaman Serai Umur 10 MST $(\mathrm{cm})$

\begin{tabular}{lllll}
\hline Perlakuan & $\mathrm{P}_{0}$ & $\mathrm{P}_{1}$ & $\mathrm{P}_{2}$ & Rerata \\
\hline $\mathrm{K}_{0}$ & 96,83 & 98,67 & 101,00 & $98,83 \mathrm{a}$ \\
$\mathrm{K}_{1}$ & 103,00 & 100,33 & 105,33 & $102,89 \mathrm{~b}$ \\
$\mathrm{~K}_{2}$ & 98,50 & 105,67 & 113,17 & $105,78 \mathrm{~b}$ \\
\hline Rerata & $99,44 \mathrm{a}$ & $101,56 \mathrm{a}$ & $106,50 \mathrm{~b}$ & \\
\hline
\end{tabular}

Keterangan: Angka-angka yang diikuti huruf yang sama pada baris atau kolom yang sama menunjukkan tidak berbeda nyata pada taraf $5 \%$ dengan menggunakan uji BNJ.

Dari tabel 1 dapat dilihat bahwa pemberian kompos janjangan sawit dengan perlakuan $9 \mathrm{~kg} /$ plot $\left(\mathrm{K}_{2}\right)$ memiliki rataan tinggi tanaman tertinggi yaitu $105,78 \mathrm{~cm}$ yang tidak berbeda nyata dengan perlakuan $4,5 \mathrm{~kg} / \mathrm{plot}\left(\mathrm{K}_{1}\right)$ dengan tinggi tanaman $102,89 \mathrm{~cm}$ tetapi berbeda nyata dengan perlakuan $0 \mathrm{~kg} / \mathrm{plot}\left(\mathrm{K}_{0}\right)$ dengan tinggi tanaman $98,83 \mathrm{~cm}$. Pemberian pupuk $\mathrm{P}$ dengan perlakuan 33,75 $\mathrm{g} /$ plot $\left(\mathrm{P}_{2}\right)$ memiliki rataan tinggi tanaman tertinggi yaitu $106,50 \mathrm{~cm}$ yang berbeda nyata dengan perlakuan $16,875 \mathrm{~g} /$ plot $\left(\mathrm{P}_{1}\right)$ dengan tinggi tanaman $101,56 \mathrm{~cm}$ dan tidak berbeda nyata dengan perlakuan $0 \mathrm{~g} / \mathrm{plot}\left(\mathrm{P}_{0}\right)$ dengan tinggi tanaman 99,94 $\mathrm{cm}$.

Analisis regresi pemberian kompos janjangan sawit terhadap tinggi tanaman serai diperoleh regresi linier dengan persamaan $\hat{Y}=99,028+0,7716 \mathrm{~K}$ dengan $r=0,98149$. Pengaruh pemberian kompos janjangan sawit terhadap tinggi tanaman serai dapat dilihat pada gambar 1 berikut ini. 


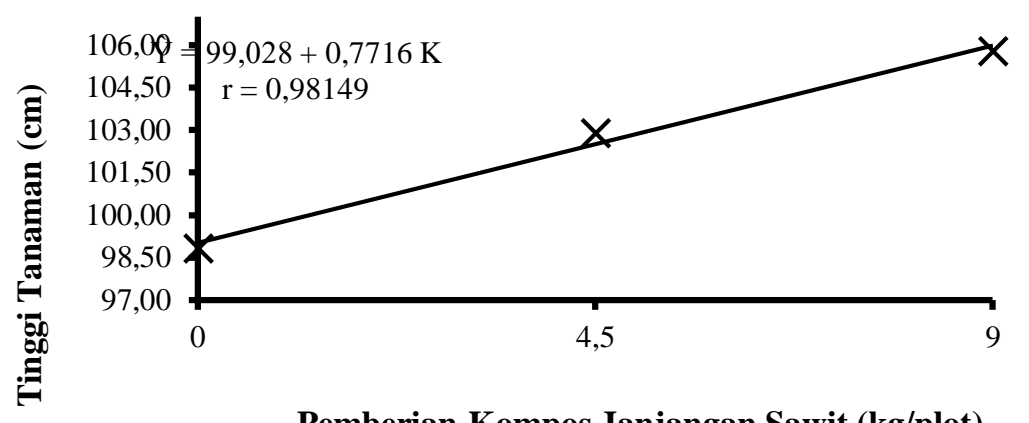

Pemberian Kompos Janjangan Sawit (kg/plot)

Gambar 1. Kurva Pengaruh Pemberian Kompos Janjangan Sawit Terhadap Tinggi Tanaman Serai $(\mathrm{cm})$

Analisis regresi pemberian pupuk $\mathrm{P}$ terhadap tinggi tanaman serai diperoleh regresi linier dengan persamaan $\hat{Y}=98,972+0,2091 \mathrm{C}$ dengan $r=0,901$. Pengaruh pemberian pupuk $\mathrm{P}$ terhadap tinggi tanaman serai dapat dilihat pada gambar 2 berikut ini.

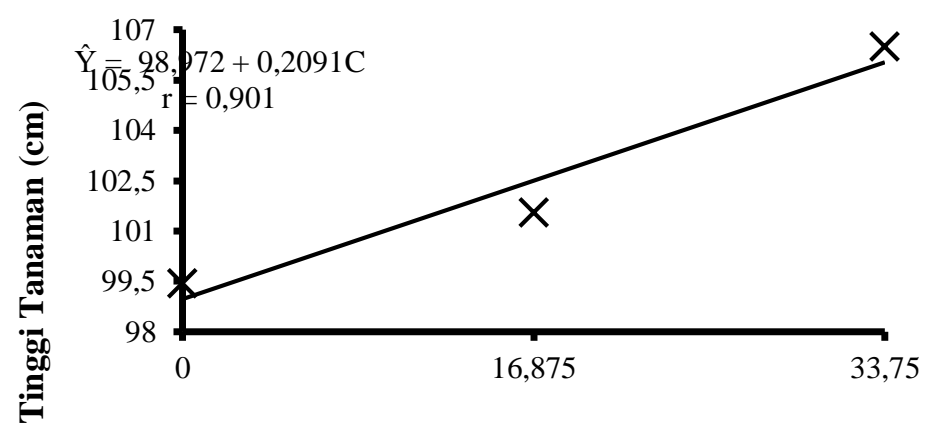

Pemberian Pupuk CIRP (g/plot)

Gambar 2. Kurva Pengaruh Pemberian Pupuk P Terhadap Tinggi Tanaman Serai $(\mathrm{cm})$

\section{Jumlah Anakan Tanaman Per Plot (batang)}

Dari hasil analisa sidik ragam diketahui bahwa pemberian kompos janjangan sawit berpengaruh nyata terhadap seluruh parameter amatan jumlah anakan tanaman perplot. Pemberian pupuk $\mathrm{P}$ berpengaruh nyata terhadap seluruh paramter jumlah anakan tanaman perplot. Interaksi pemberian kompos jumlah anakan dan pupuk $\mathrm{P}$ menunjukkan tidak berpengruh nyata terhadap seluruh parameter amatan jumlah anakan tanaman perplot.

Hasil uji beda rataan pengaruh pemberian kompos janjangan sawit dan pupuk $\mathrm{P}$ terhadap jumlah anakan tanaman perplot umur $10 \mathrm{MST}$ dapat dilihat pada tabel 2 berikut ini.

Tabel 2. Hasil Uji Beda Rataan Pengaruh Pemberian Kompos Janjangan Sawit dan Pupuk P Terhadap Jumlah Anakan Tanaman Perplot Umur 10 MST (batang)

\begin{tabular}{lllll}
\hline Perlakuan & $\mathrm{P}_{0}$ & $\mathrm{P}_{1}$ & $\mathrm{P}_{2}$ & Rerata \\
\hline $\mathrm{K}_{0}$ & 132,67 & 126,67 & 142,67 & $134,00 \mathrm{a}$ \\
$\mathrm{K}_{1}$ & 147,33 & 155,67 & 170,33 & $157,78 \mathrm{~b}$
\end{tabular}




\begin{tabular}{lllll}
$\mathrm{K}_{2}$ & 175,33 & 178,33 & 180,67 & $178,11 \mathrm{~b}$ \\
\hline Rerata & $151,78 \mathrm{a}$ & $153,56 \mathrm{a}$ & $164,56 \mathrm{~b}$ & \\
\hline
\end{tabular}

Keterangan: Angka-angka yang diikuti huruf yang sama pada baris atau kolom yang sama menunjukkan tidak berbeda nyata pada taraf $5 \%$ dengan menggunakan uji BNJ.

Dari tabel 2 dapat dilihat bahwa pemberian kompos janjangan sawit dengan perlakuan $9 \mathrm{~kg} /$ plot $\left(\mathrm{K}_{2}\right)$ memiliki rataan jumlah anakan perplot tanaman terbanyak yaitu 178,11 batang tidak saling berbeda nyata dengan perlakuan 4,5 $\mathrm{kg} / \mathrm{plot}\left(\mathrm{K}_{1}\right)$ dengan jumlah anakan tanaman perplot 157,78 batang tetapi berbeda nyata dengan perlakuan $0 \mathrm{~kg} / \mathrm{plot}\left(\mathrm{K}_{0}\right)$ dengan jumlah anakan tanaman perplot 134,00 batang. Pemberian pupuk $\mathrm{P}$ dengan perlakuan $33,75 \mathrm{~g} / \mathrm{plot}\left(\mathrm{P}_{2}\right)$ memiliki rataan jumlah anakan tanaman perplot terbanyak yaitu 164,56 batang yang berbeda nyata dengan perlakuan $16,875 \mathrm{~g} / \mathrm{plot}\left(\mathrm{P}_{1}\right)$ dengan jumlah anakan tanaman perplot 153,56 batang tetapi tidak berbeda nyata dengan perlakuan 0 $\mathrm{g} /$ plot $\left(\mathrm{P}_{0}\right)$ dengan jumlah anakan tanaman perplot 151,78 batang.

Analisis regresi pemberian kompos janjangan sawit terhadap jumlah anakan tanaman perplot diperoleh regresi linier dengan persamaan $\hat{Y}=134,57+$ $4,9012 \mathrm{~K}$ dengan $\mathrm{r}=0,996$. Pengaruh pemberian kompos janjangan sawit terhadap jumlah anakan tanaman perplot dapat dilihat pada gambar 3 berikut ini.

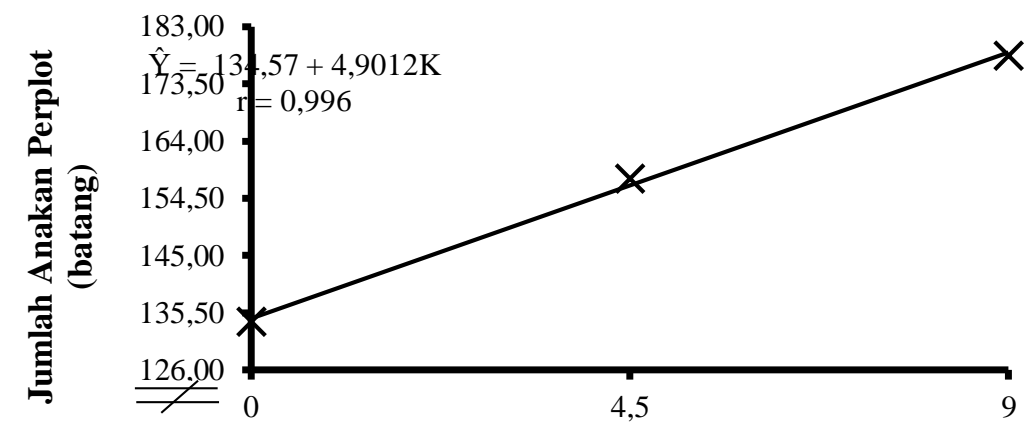

\section{Pemberian Kompos Janjangan Sawit (kg/plot) \\ Gambar 3. Kurva Pengaruh Pemberian Kompos Janjangan Sawit Terhadap Jumlah Anakan Tanaman Perplot (batang)}

Analisis regresi pemberian pupuk $\mathrm{P}$ terhadap jumlah anakan tanaman perplot diperoleh regresi linier dengan persamaan $\hat{Y}=150,24+0,378 \mathrm{C}$ dengan $r$ $=0,726$. Pengaruh pemberian pupuk $\mathrm{P}$ terhadap jumlah anakan tanaman perplot dapat dilihat pada gambar 4 berikut ini. 


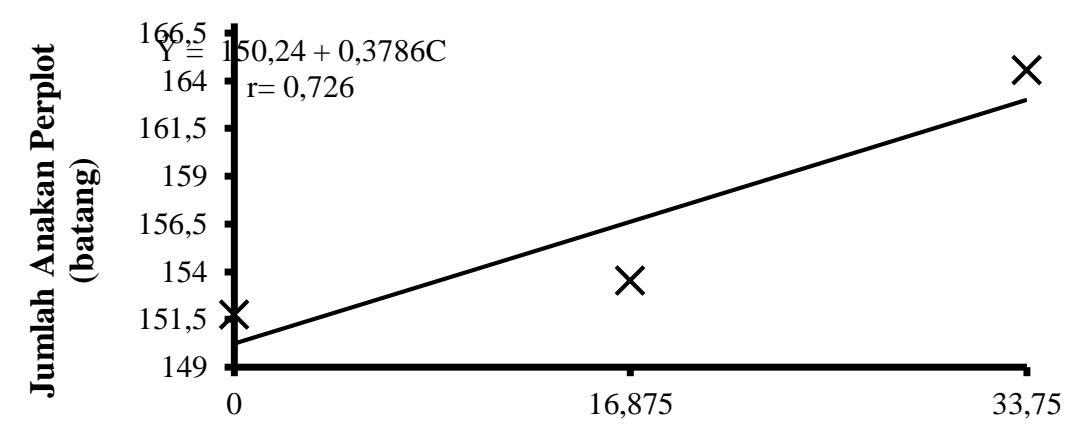

Pemberian Pupuk CIRP (g/plot)

Gambar 4. Kurva Pengaruh Pemberian Pupuk P Terhadap Jumlah Anakan Tanaman Perplot (batang)

\section{Produksi Tanaman Per Plot (gr)}

Dari hasil analisa sidik ragam diketahui bahwa pemberian kompos janjangan sawit berpengaruh nyata terhadap produksi tanaman perplot. Pemberian pupuk $\mathrm{P}$ berpengaruh nyata terhadap produksi tanaman perplot. Interaksi pemberian kompos dan pupuk $\mathrm{P}$ menunjukkan tidak berpengruh nyata terhadap produksi tanaman produksi tanaman perplot.

Hasil uji beda rataan pengaruh pemberian kompos janjangan sawit dan pupuk $\mathrm{P}$ terhadap produksi tanaman produksi tanaman perplot dapat dilihat pada tabel 3 berikut ini.

Tabel 3. Hasil Uji Beda Rataan Pengaruh Pemberian Kompos Janjangan Sawit dan Pupuk P Terhadap Produksi Tanaman Perplot (g)

\begin{tabular}{lllll}
\hline Perlakuan & $\mathrm{P}_{0}$ & $\mathrm{P}_{1}$ & $\mathrm{P}_{2}$ & Rerata \\
\hline $\mathrm{K}_{0}$ & 1476,67 & 1846,67 & 2063,33 & $1795,56 \mathrm{a}$ \\
$\mathrm{K}_{1}$ & 2240,00 & 2342,00 & 2340,00 & $2307,33 \mathrm{a}$ \\
$\mathrm{K}_{2}$ & 2372,33 & 2936,67 & 3580,33 & $2963,11 \mathrm{~b}$ \\
\hline Rerata & $2029,67 \mathrm{a}$ & $2375,11 \mathrm{~b}$ & $2661,22 \mathrm{~b}$ & \\
\hline
\end{tabular}

Keterangan: Angka-angka yang diikuti huruf yang sama pada baris atau kolom yang sama menunjukkan tidak berbeda nyata pada taraf $5 \%$ dengan menggunakan uji BNJ.

Dari tabel 3 dapat dilihat bahwa pemberian kompos janjangan sawit dengan perlakuan $9 \mathrm{~kg} / \mathrm{plot}\left(\mathrm{K}_{2}\right)$ memiliki rataan produksi tanaman perplot terberat yaitu $2963,11 \mathrm{~g}$ berbeda nyata dengan perlakuan $4,5 \mathrm{~kg} / \mathrm{plot}\left(\mathrm{K}_{1}\right)$ dengan produksi tanaman perplot $2307,33 \mathrm{~g}$ tetapi tidak berbeda nyata dengan perlakuan $0 \mathrm{~kg} /$ plot $\left(\mathrm{K}_{0}\right)$ dengan produksi tanaman perplot 1795,56 $\mathrm{g}$. Pemberian pupuk $\mathrm{P}$ dengan perlakuan $33,75 \mathrm{~g} / \mathrm{plot}\left(\mathrm{P}_{2}\right)$ memiliki rataan produksi tanaman perplot terberat yaitu $2661,22 \mathrm{~g}$ yang tidak berbeda nyata dengan perlakuan $16,875 \mathrm{~g} / \mathrm{plot}$ $\left(\mathrm{P}_{1}\right)$ dengan produksi tanaman perplot $2375,11 \mathrm{~g}$ tetapi berbeda nyata dengan perlakuan $0 \mathrm{~g} /$ plot $\left(\mathrm{P}_{0}\right)$ dengan produksi tanaman perplot 2029,67 $\mathrm{g}$.

Analisis regresi pemberian kompos janjangan sawit terhadap produksi tanaman perplot diperoleh regresi linier dengan persamaan $\hat{Y}=1771,6+129,73 \mathrm{~K}$ dengan $r=0,990$. Pengaruh pemberian kompos janjangan sawit terhadap produksi tanaman perplot dapat dilihat pada gambar 5 berikut ini. 


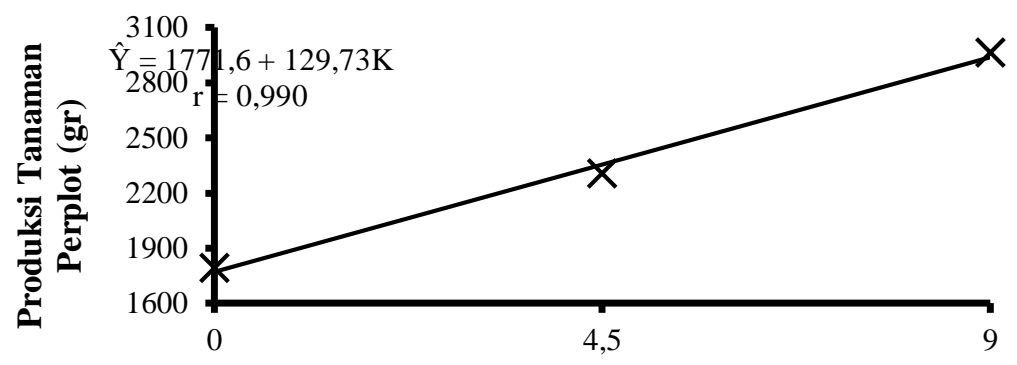

Pemberian Kompos Janjangan Sawit (kg/plot)

Gambar 5. Kurva Pengaruh Pemberian Kompos Janjangan Sawit Terhadap Produksi Tanaman Perplot (g)

Analisis regresi pemberian pupuk $\mathrm{P}$ terhadap produksi tanaman perplot diperoleh regresi linier dengan persamaan $\hat{Y}=2039,6+418,713 \mathrm{C}$ dengan $\mathrm{r}=$ 0,994 . Pengaruh pemberian pupuk $\mathrm{P}$ terhadap produksi tanaman perplot dapat dilihat pada gambar 6 berikut ini.

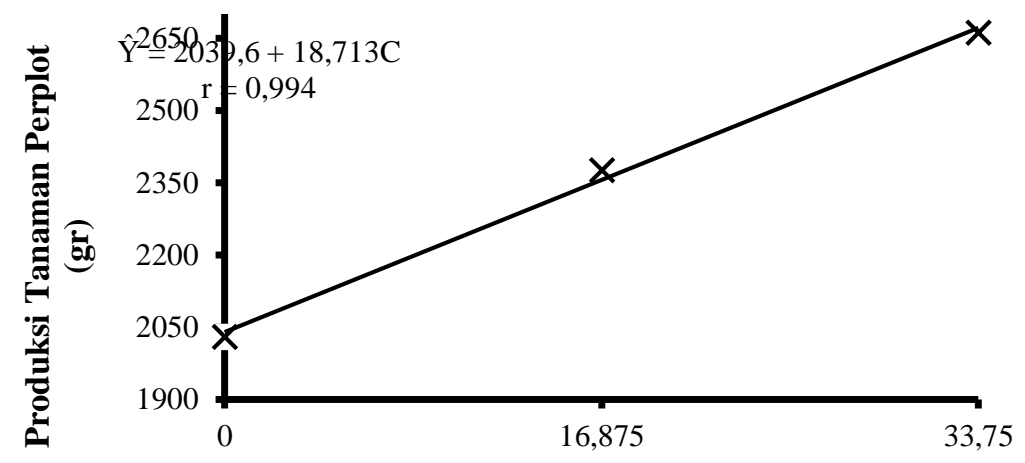

Pemberian Pupuk CIRP (g/plot)

Gambar 6. Kurva Pengaruh Pemberian Pupuk P Terhadap Produksi Tanaman Perplot (g)

\section{PEMBAHASAN}

\section{Pengaruh Pemberian Kompos Tandan Kosong Kelapa Sawit Terhadap Pertumbuhan dan Produksi Tanaman Serai}

Dari analisis sidik ragam dapat dilihat bahwa pemberian kompos tandan kosong kelapa sawit berengaruh nyata terhadap seluruh paramater amatan tanaman serai.

Pemberian bahan organik merupakan upaya untuk memenuhi unsur hara bagi tanaman dan meningkatkan daya dukung lahan. Bahan organik merupakan salah satu faktor penentu tingkat kesuburan tanah, baik sifat fisik, kimia dan biologi tanah yang secara langsung dipengaruhi oleh ketersediaan bahan organik tanah (Aminah $d k k, 2015$ ). Sejalan dengan pendapat Oviasogie dkk (2013), bahwa pupuk organik merupakan sumber nutrisi tanah yang dihasilkan dari bahan-bahan organik yang berasal dari sisa-sisa tanaman atau berasal dari kotoran hewan. Pupuk organik memiliki keuntungan untuk menggemburkan tanah, meningkatkan hasil panen, tanaman 
tumbuh lebih baik, mampu melindungi tanaman dari penyakit tertentu, aman dan lebih murah dari pada pupuk kimia serta lebih ramah lingkungan.

Adanya pengaruh pemberian tandan kosong kelapa sawit karena kompos tandan kosong kelapa sawit memiliki kandungan unsur hara yang mampu meningkatkan dan mamperbaiki pertumbuhan tanaman serai. Pupuk organik yang diaplikasikan ke lahan akan mengalami dan melepaskan unsur-unsur hara yang dibutuhkan oleh tanaman baik unsur hara makaro maupun mikro. Kompos tandan kosong merupakan pupuk organik yang mengandung unsur hara utama yang dibutuhkan tanaman yaitu $\mathrm{N}, \mathrm{P}, \mathrm{K}$ dan $\mathrm{Mg}$ dan unsur-unsur mikro (Mustaqim, 2016).

Menurut Hayat dan Andayani (2014), kompos tandan kosong kelapa sawit mamiliki kandungan hara $\mathrm{N}$ total $(1,91 \%), \mathrm{K}(1,51 \%), \mathrm{Ca}(0,83 \%), \mathrm{P}(0,54 \%), \mathrm{Mg}$ (0,09\%), C-organik (51,23\%), C/N ratio 26,82\%, dan memilki $\mathrm{pH} 7,13$. Pupuk organik tandan kosong kelapa sawit memilki fungsi ganda selain sebagai ketersediaan hara dalam tanah, juga untuk meningkatkan kandungan bahan organik tanah yang diperlukan sebagai perbaikan sifat fisik, kimia dan biologi tanah. Perbaikan sifat tanah tersebut berdampak positif terhadap pertumbuhan akar tanaman dan penyerapan unsur hara (Rozy $d k k$, 2013).

Tandan kosong kelapa sawit merupakan limbah padat yang dihasilkan dlam industri minyak sawit. Jumlah tandan kosong kelapa sawit ini cukup besar jumlahnya hampir sama dengan umlah produksi minyak mentah. Tandan kosong kelapa sawit mengandung serat yang tinggi. Kandungan utama tandan kosong kelapa sawit adalah selulos dan lignin selain itu juga mengandung unsur organik dalam sampel kering): 42,8\% C; 0,80\% N; 0,22\% P2O5; 0,30\% MgO; 0,09\% K2O (Firmansyah, 2010).

Kompos tandan kosong kelapa sawit memiliki kandungan hara yang cukup sehingga mampu menunjang pertumbuhan hingga sampai produksi tanaman serai. Munawar (2011) menyatakan bahwa ketersediaan unsur hara dalam jumlah cukup dan terpenuhi, dapat berpengaruh terhadap tumbuh dan berkembangnya tanaman sehingga menghasilkan produksi sesuai dengan potensi.

Kompos juga memiliki fungsi untuk mrngemburkan tanah sehingga mempermudah perkembangan akar dan meningkatan kemampuannya dalam penyerapan hara secara optimal (Onggo $d k k$, 2017). Sependapat dengan Elmizan (2014) kompos berperan sangat baik dalam memperbaiki sifat fisik dan kimia serta memperbaiki struktur tanah.

Dari hasil penelitian yang dilakukan bahwa pemberian kompos tandan kosong kelapa sawit dengan dosis $9 \mathrm{~kg} /$ plot menunjukkan pengaruh terbaik. Ini menunjukkan bahwa kompos tandan kosong kelapa sawit memiliki kandungan unsur hara yang cukup untuk menunjang pertumbuhan tanaman serai serta mampu meningkatkan hasil tanaman serai. Sejalan dengan Munawar (2011), menyatakan bahwa ketersediaan unsur hara dalam jumlah yang cukup dan terpenuhi dapat berpengaruh terhadap pertumbuhan dan perkembangan tanaman sehingga mampu berproduksi sesuai potensi.

\section{Pengaruh Pemberian Pupuk P Terhadap Pertumbuhan dan Produksi Tanaman Serai}

Dari analisis sidik ragam dapat dilihat bahwa pemberian pupuk $\mathrm{P}$ berengaruh nyata terhadap seluruh paramater amatan tanaman serai. Pupuk $\mathrm{P}$ 
merupakan pupuk dengan kandungan Posphat sebesar 28\%. Phospat berfungsi sebagai merangsang pertumbuhan akar, memperkuat akar dan batang dan mampu maningkatkan jumlah anakan. Hal ini sependapat dengan Abdulrachman $d k k$ (2009), bahwa pada tanaman padi $\mathrm{P}$ sangat diperlukan terutama pada awal pertumbuhan tanaman. Pada fase pertumbuhan tanaman tersebut, $\mathrm{P}$ berfungsi untuk memcau pembentukan akar dan penambahan jumlah anakan.

Agustina (2007) menyatakan, bahwa fosfor berfungsi sebagai pembentuk energi hasil dari metabolisme dalam tanaman, merangsang pembungaan dan pembuahan, pertumbuhan akae, pembentukan biji, pembelahan sel tanaman dan memperbesar jaringan sel. Serta berperan dalam pembentukan membran sel fosfolipid.

Selain sangat diperlukan sebagai pembentukan akar, unsur hara $\mathrm{P}$ juga berperan dalam proses fotosintesis, penggunaan gula dan pati, serta transfer energi. Defesiensi P mengakibatkan pertumbuhan tanaman menjadi terhambat, lemah dan biasanya dicirikan dengan kekerdilan (Sumarni $d k k, 2012$ ).

Pada data pengamatan dapat dilihat bahwa pemberian terbaik pupuk $\mathrm{P}$ pada semua parameter amatan yang diamati yaitu pada dosis $0,03 \mathrm{~g} / \mathrm{plot}$. Dapat dilihat bahwa pada dosis $0,03 \mathrm{~g} /$ plot sudah mampu mencukupi kebutuhan hara untuk memacu pertumbuhan dan perkembangan tanaman serai. Kusmanto (2010) menegaskan, bahwa untuk mencapai eesiensi pemupukan yang optimal, pupuk harus diaberikan dalam jumlah yang mencukupi untuk keberlangsungan pertumbuhan dan perkembangan tanaman tersebut. Pemberian yang dilakukan tidak terlalu banyak dan tidak pula terlalu sedikit. Karena jika pemberian pupuk secara berlebihan bisa mengakibatkan tanaman tersebut keracunan, dan sebaiknya jika terlalu sedikit pengaruh pemupukan tidak akan tampak terhadap pertumbuhan dan perkembangan dari suatu tanaman.

\section{Pengaruh Interaksi Pemberian Kompos Tandan Kosong Kelapa Sawit dan Pupuk P Terhadap Pertumbuhan dan Produksi Tanaman Serai}

Dari hasil analisis sidik ragam dapat diketahui bahwa interaksi pemberian kompos tandan kosng kelapa sawit dan pupuk $\mathrm{P}$ tidak menunjukkan pengaruh nyata terhadap seluruh parameter amatan tanaman serai.

Pemupukan merupakan upaya yang ditempuh untuk memaksimalkan hasil dari tanaman. Wijaya (2008) menyatakan, bahwa pemupukan adalah uapaya yang dilakukan untuk mencukupi kebutuhan hara tanaman agar tujuan untuk mendapatkan prouksi yang maksimal dapat dicapai. Akan tetapi jika penggunaan pupuk tidak diberikan secara bijak atau berlebihan dapat menimbulkan masalah bagi tanaman yang dibudidayakan, seperti keracunan, rentan akan hama dan penyakit, kualitas produksi rendah dan tingginya biaya produksi hingga dapat menimbulkan pencemaran yang berujung merusak lingkungan.

Sesuai dengan pendapat Bustami $d k k$ (2012), berpendapat bahwa pertumbuhan dan produksi tanaman akan mencapai optimum apabila faktor penunjang mendukung pertumbuhan tersebut berada dalam keaadan optimal, unsur-unsur yang seimbang, dosis pupuk yang tepat serta hara yang dibutuhkan oleh tanaman tersedia untk tanaman. Pemberian pupuk yang tepat dengan dosis dan kebutuhan dapat meningkatkan produksi, sebalikanya pemberian yang berlebihan justru akan menurunkan produksi dari tanaman. 
Abdulrachman $d k k$ (2009) menyatakan, bahwa kemampuan tanah dalam menyediakan hara bagi tanaman tergantung pada:

1. kapasitas tanah dalam menyuplai hara

2. daya ikat dan melepas hara, dan

3. mobilitas hara.

Pada umumnya pertumbuhan dan perkembangan tanaman dipegaruhi oleh faktor internal (genetik) dan faktor eksternal (lingkungan). Faktor internal contonya seperti hormon dan keturuan dari tanaman itu sendiri, sedangkan faktor eksternal contonya yaitu nutrisi/hara, cahaya, $\mathrm{pH}$ tanah, kelembaban, suhu dan oksigen. Dan faktor aktor lainnya yang menyebabkan kurang berpengaruhnya pemberian pupuk terhadap pertumbuhan dan perkembangan tanaman.

\section{KESIMPULAN}

1. Ada pengaruh pemberian kompos janjangan sawit terhadap seluruh parameter amatan tanaman serai dengan perlakuan terbaik yaitu $9 \mathrm{~kg} / \mathrm{pot}$.

2. Ada pengaruh pemberian pupuk $\mathbf{P}$ terhadap seluruh parameter amatan tanaman serai dengan perlakuan terbaik yaitu 33,75 g/pot.

3. Tidak ada pengaruh interaksi pemberian kompos janjangan sawit dan pupuk $\mathrm{P}$ terhadap seluruh parameter amatan tanaman serai.

\section{DAFTAR PUSTAKA}

Abdulrachman, S., H. Sembiring, dan Suyamto. 2009. Pemupukan Tanaman Padi. Balai Besar Penelitian tanaman Padi. Pusat penelitian dan Pengembangan Tanaman Pangan, Jakarta.

Agustina L. 2007. Dasar Nutrisi Tanaman. Penerbit Rineke Cipta. Jakarta.

Aminah. Vandalita M.M R dan Herliani. 2015. Abu Janjang Kelapa Sawit Dan Kotoran Ayam Sebagai Pupuk Organik Serta Pengaruhnya Terhadap Pertumbuhan Dan Hasil Tanaman Kacang Hijau (Vigna Radiata L) Sebagai Penunjang Mata Kuliah Fisiologi Tumbuhan. Universitas Mulawarman. Samarinda.

Bustami, Sufardi, dan Bahtiar. 2012. Serapan Hara dan Efesiensi Pemupukan Fosfat Serta Pertumbuhan Padi Varitas Lokal. Fakultas Pertanian, Umsyiah. Banda Aceh. Jurnal Manajemen Sumberdaya Lahan. 1: 159170

Ewansiha, J. U., Garba, S. A., Mawak, J. D., dan Oyewole, O. A. 2012. Antimicrobial Activity of Cymbopogon citratus (Lemon Grass) and It's Phytochemical Properties. Frontiers in Science. 2(6):214-220.

Fauzi, A. 2009. Aneka Tanaman Obat dan Khasiatnya. Yogyakarta: Penerbit Media Pressindo. 
Firmansyah, A. M. (2010). Teknik Pembuatan Kompos. Kalimantan Tengah: Balai Pengkajian Teknologi Pertanian.

Jannah. N., A. Fatah dan Marhannudin. 2012. Pengaruh Macam dan Dosis Pupuk NPK Majemuk Terhadap Pertumbuhan Bibit Kelapa Sawit (Elaeis guineensis Jack). Media Sains 4 (1): 48-50 Fakultas Pertanian Universitas Samarinda

Lingga, P dan Marsono. 2004. Petunjuk Penggunaan Pupuk. Penebar Swadaya. Jakarta.

Mubandono, L. 2005. Membuat Kompos. Ed. Rev. Penebar Swadaya. Jakarta.

Munawar, A. 2011. Kesuburan Tanah Dan Nutrisi Tanaman. IPB Press. Penebar Swadaya. Jakarta

Musnawar. 2007. Petunjuk Penggunaan Pupuk Kalsium dan Magnesium. Penebar Swadaya. Jakarta.

Mustaqim, R., Armaini., A.E. Yulia. 2016. Pengaruh Pemberian Kompos Tandan Kosong Kelapa Sawit dan Pupuk NPK Terhadap Pertumbuhan dan Produksi Tanaman Melon (Cucumis melo L). Jurnal Online Mahasiswa Fakultas Pertanian. 2 (1), 1-13.

Onggo, T.M, Kusumiyati, A. Nurfitriana. 2017. Pengaruh penambahan arang sekam dan ukuran polybag terhadap pertumbuhan dan hasil tanaman tomat kultivar 'valouro' hasil sambung batang. Jurnal Kultivasi, 16 (1), 298-304.

Oviasogie, P. O., Odewale, J. O., Aisueni, N. O., Eguagie, E. I., Brown, G., \& OkohOboh, E. (2013). Production, utilization and acceptability of organic fertilizers using palms and shea tree as sources of biomass. African Journal of Agricultural Research, 8(27), 3483-3494.

Purnamayani, R., B.S. Busyra, P. Hendri, dan E. Syafri. 2012. Kajian Pemanfaatan Kompos Tandan Kosong Kelapa Sawit Sebagai Substitusi Pupuk Kalium Mendukung Pertanian Sayuran Organik di Provinsi Jambi.Laporan Akhir Insentif Peningkatan Kemampuan Peneliti dan Perekayasa. PKPP, Jambi.

Rozy, F., Rosmawaty, T., \& Fatrrahman. (2013). Pemberian pupuk N P K mutiara 16:16:16 dan kompos tandan kosong kelapa sawit pada tanaman terung (solanum melongena L). Jurnal RAT, 1(2), 228-239.

Setiadi, D., Noertjahyani, dan Suparman. 2018. Perbedaan kualitas dan vase life bunga krisan akibat aplikasi macam pupuk organik dengan variasi jarak tanam. Jurnal Kultivasi. 17 (1).587-595. Universitas padjadjaran 
Simanungkalit, R. D. M. 2013. Tiga Belas Prospek Pemupukan Balittanah. Litbang. Deptan. go. id/.../13 prospek\%2 pupuk (Diakses 22 Januari 2019).

Sumarni, N., R. Roslina, dan Suwandi. 2012. Optimasi jarak dan dosis pupuk NPK untuk produksi bawang merah dari benih umbi mini di dataran tinggi. J. Hort. 22(2): 148-155.

Sutanto R, 2002. Pertanian organik menuju pertanian alternatif dan berkelanjutan. Kanisius. Yogyakarta.

Sutanto, R. 2002. Penerapan Pertanain Organik Pemasyarakatan dan Pengembangannya. Kanisius. Yogyakarta.

Tim Karya Tani Mandiri. 2010. Pedoman Bertanam Jagung. Nuansa Aulia. Bandung.

Wijayakusuma. 2005. Buku Ajar Fisiologi Kedokteran. EGC. Jakarta.

Wijoyo, P. M. 2009. 15 Ramuan Penyembuh Maag. Bee Media Indonesia. Jakarta.

Winarsi, H. 2007. Antioksidan Alami \& Radikal Bebas. Yogyakarta: Penerbit Kanisius

Winarso S. 2005. Kesuburan Tanah; Dasar Kesehatan dan Kualitas Tanah. Gava Media. Yogyakarta.

Yuwono, Teguh. 2006. Kecepatan dekomposisi dan kualitas kompos sampah organik. Jurnal inovasi pertanian 